\title{
The development of skills in Primary Health Care nurses for coping with social inequalities in health
}

\author{
Nayara Rodrigues Carvalho'(i), Andréia Patrícia Gomes'(i), \\ Érica Toledo de Mendonça'(D) Amanda Morais Polati"(i), \\ Vanessa de Souza Amaral'(D), Tiago Ricardo Moreiral' ${ }^{1}$, \\ Deíse Moura de Oliveira'(i)
}

\author{
'Universidade Federal de Viçosa, Viçosa, MG, Brasil \\ "Universidade Federal do Espirito Santo, Vitória, ES, Brasil
}

\begin{abstract}
The objective of this study was to identify and develop skills with Primary Health Care nurses to work the social inequalities in health. This is a qualitative research based on action-research, performed with six primary health care nurses in a municipality of Minas Gerais, who participated in educational workshops addressing coping strategies for social inequalities in health. The data collection occurred through a focal group and non-participant observation, from March to May 2018. The data were analyzed through the thematic content analysis technique. The identification and training of skills to cope with this was founded on knowledge, skills and attitudes. The participants stressed the importance of knowing their role in the scenario where they work, as well as the functioning of the Health Care Network and legislation to support them to coping with this problem, being the communicational skills essential in this process. The knowledge acquired in the workshop enabled participants to recognize attitudes in their professional routine, which enable them to act in the face of this reality. The present study indicates the importance of appreciating and strengthening the training of nurses for the development of competences to act on social inequalities.
\end{abstract}

Keywords: Nurses; Professional Training; Social Inequity; Primary Health Care 


\section{INTRODUCTION}

The 1988 Federal Constitution established the social security as a public policy, in an attempt to ensure a more cohesive, egalitarian and fair society to all citizens, guaranteeing universal, free and quality health and education (BORGES; AMARAL, 2015). Brazil has been undergoing, in recent decades, scientific and technological advances, which have gradually affected the reduction of social inequalities, because, over the years, the citizens are having more access to goods and services. However, this development has still not fairly reached all regions of the country (PAIM et al., 2011).

Therefore, even with sanitary and socioeconomic improvements in Brazil, social inequalities are still an important public health problem that permeates throughout the years. They appear as power relations, access to services, possession of goods, wealth, education, race and ethnicity, sex and housing or work conditions make individuals socially vulnerable (BARRETO, 2017).

Social inequalities reflect how social relations and the worldview of people are defined. These are influenced by the context surrounding the individual and the historic moment lived, affecting the unequal access to health services, education and income, which often do not provide the possibility to cultivate healthy life habits. All these factors can generate situations of distress and anguish, which can corroborate to a worsening of the disease process of individuals and collectivities (BORGES; AMARAL, 2015).

This corroborates the Heath Social Determinants (HSD), which interfere and negatively affect the health of the population, culminating in losses often preventable, which characterize the social inequalities in health (BUSS; PELLEGRINI, 2007).

Thinking of a more equitable health care presupposes the previous recognition of situations of social inequality in the country, which interfere directly in the universal right to health. In this context, the first step of those who work in 
the healthcare sector must be to recognize the social inequalities, in order to think and make strategies to act effectively on them (AITH; CARVALHO, 2015).

Implementing the social rights in a country of extreme social inequality, like Brazil, is to consider equity as a founding principle to equalize the social abyss that reigns in our society. Thus, the search for equity in health becomes a priority, being strengthened in the principles of the Unified Health System (UHS) (BARROS; SOUSA, 2016).

In this perspective, there is the Primary Health Care $(\mathrm{PHC})$, considered the main entrance door of users in the health system, in which the Family Health Strategy (FHS) is the attempt to reorganize the assistance at this care level, in order to ensure that the principles of the UHS are offered to all users equitably (ARANTES; SCHIMIZU; MERCHAN-HERMANN, 2016; FERTONANI et al., 2015).

Such guarantee of quality and equitable assistance foresees the need for competent professionals to act in the UHS, understanding that this competence arises from knowledge, skills and attitudes to promote the care in a context marked by social inequalities (FERNANDES et al., 2013).

In this sense, the nurse stands out, who has an expressive performance in the UHS, and especially in the PHC. In this care locus, in particular, he/she sees his/her work affected by social issues that impact directly on the health of individuals, families and communities, requiring this professional a coping posture while facing this reality (FERNANDES et al., 2013).

The Brazilian Nursing has proposed to revise its training so that students are able to act in the UHS context, path announced with the National Curricular Guidelines for the Nursing Graduate Course DCN/ENF, approved in 2001. In this sense, there stand out the skills involved in knowing how to recognize, how to do, how to cope and how to be, required dimensions for the professional be able to identify and act upon the complexity that permeates health issues within the biopsychosocial context (LEONELLO; OLIVEIRA, 2008; BRASIL, 2001; FERNANDES et al., 2013). 
The empirical observation of the practice allows evidencing that the nurse's practice in the PHC is marked by the need to give answers to social problems that people live in everyday life, which commonly set as a great challenge for these professionals in this health care scenario. Added to this, there is a gap regarding the scientific production related to the skills necessary for the nurse to act on social inequalities in health, which justifies the accomplishment of this research.

Therefore, considering the importance of the nurse's performance in the UHS and the changes experienced by this professional in the PHC, referring to social inequalities present in the health territory, the following question guided the present study: What are the skills necessary for the nurse to work the social inequalities in health? How to build these skills together with nurses who work in the PHC context?

In this sense, the objective of this study was to identify and develop skills with PHC nurses to work the social inequalities in health.

\section{METHODOLOGY}

This is a qualitative research based on the research-action. This is a type of social research with empirical basis, designed and carried out in close association with an action, which seeks the resolution of a collective problem, in which there is a mutual co-responsibility of those involved in the investigated problem (THIOLLET, 2008).

This research method involves the intervention of a collective problem found in professional practice, which aims to change this reality through the active participation of professionals inserted in this process, who seek, through the junction of theory and practice, to solve the problem through changes in attitude in relation to the work scenario (THIOLLET, 2008; TRIPP, 2005).

Thus, the research-action contributes to improving practice, through the systematic oscillation between the action and investigation in professional 
performance. In this sense, the strategic actions are based on four phases of the basic cycle of the research-action, namely: planning, implementation, description and evaluation. The characteristics present in this methodological modality innovative, continuous, strategically proactive, participatory, interventionist, problematizing, documented, understood and disseminated - perpetuate throughout the course of the research (TRIPP, 2005).

The participants were nurses working in the PHC in a municipality located in Zona da Mata in Minas Gerais, with a population of approximately 70,000 thousand inhabitants, distributed in a territorial area of about 200,000 km2 (IBGE, 2015). At the time of data collection, it had 16 Health Units, totaling 18 teams registered in the Family Health Strategy (FHS), all with a nurse as a member.

The inclusion criteria were to be the 11 nurses who agreed to participate in a previous research coordinated by the researchers of this study entitled "Experiences of social inequality in the perspective of nurses in Primary Health Care: challenges, feelings and coping", whose objective was to understand the experiences of PHC nurses regarding their performance on social inequalities in health. The results from this previous research culminated in the identification of critical knots related to coping with social inequalities by PHC nurses, guiding the delineation of this research-action.

The exclusion criterion established was being on leave by any reason in the data collection period or non-adherence to the workshops of those who accepted to participate in the research. Of the 11 nurses potentially included, eight agreed to participate, but two were not present in all the workshops. There were three refusals, which were related to non-availability to attend the activities proposed in this research, totaling six nurses as participants in the whole research process.

The participants received information on the research objective and on the right to participate or not in the same, which was legitimized by signing the Informed Consent Form (ICF). 
The intervention occurred from March to May 2018, through four in-person workshops, on days scheduled according to the availability of participants. The instrument of data collection was the focal group and the non-participant observation.

The focal group is characterized by group interviews, based on the communication and interaction of the group, aiming to gather detailed information on specific topics. This interaction fosters the exchange of information, providing an understanding of the topic (SCHVINGEL; GIONGO; MUNHOZ, 2017).

The non-participant observation was performed in all workshops, by one of the researchers of the research team, who recorded in the field diary the verbal and non-verbal language of what occurred in the course of the same, in order to enrich the record of the meanings that emerged.

The first workshop was developed having as a methodological strategy the cine debate, with a documentary that aimed to problematize and sensitize the participants on the addressed topic, retrieving the professional practice and gaps in the coping process of social inequalities in health.

In the second workshop, there was the questioning about the abilities necessary to work the social inequalities, aiming to generate reflections on the professional activity in this context, thereby diminishing the sense of powerlessness evidenced in the research in which they previously participated. This workshop brought to light the importance of communication with other sectors and actors so that nurses could develop their skills to cope with inequalities, emerging the dialog with the network as a need.

In this perspective, there was the third workshop, opening a space for dialog among professionals working in the health care network of the municipality (from the department of health and social care) and the PHC nurses. It aimed to approach and facilitate the intra and intersectoral communication, considered, in the previous research, as the core of the challenges experienced by nurses to cope with social inequalities in the PHC. 
In the fourth and last workshop, there was the focal group, aiming to enable the consolidation of the theme in professional practice, as well as to evaluate the evolution of learning regarding the construction of competences in the nurses for coping with social inequalities in health.

The researcher conducted the focal group through the following guiding questions: how did these workshops mobilize me about my role in coping with social inequalities in health? What skills have I developed in these workshops for coping with social inequalities in health? Considering these competences, what do I acknowledge today that I already do in my practice to work the social problems I experience in the PHC? How can the workshops affect my performance on the social inequalities from now on?

The workshops were reconfigured according to the main role and needs of participants and were guided by active teaching methodologies, in which the main objective would be to identify and build, along with nurses, the skills necessary to work the social inequalities in the territory, allowing developing a critical thinking and a praxis coherent with the context in which they worked.

They were asked permission to use the recorder in the last workshop, when the focal group was carried out, for subsequent transcription of speeches in their entirety. To ensure anonymity, the participants were identified with the letter " $G$ " (Group), followed by the Arabic numeral corresponding to each participant, ordered from the first speech of each nurse in the focal group (ex: $G 1, \ldots, G 6$ ).

The data collected were organized into study categories, from the main ideas present in the interviewees' statements and analyzed according to Content Analysis technique of Lawrence Bardin, composed of the following steps: (1) pre-analysis, (2) exploration of the material, (3) treatment of the results obtained, and (4) interpretation (Bardin, 2016).

The present study followed the ethical precepts contained in Resolution $466 / 2012$ of the National Council of Research Ethics, obtaining a favorable opinion 
from the Human Research Ethics Committee (CEP) of the Federal University of Viçosa (UFV) (Opinion n. 2.058.819 /CAAE 67962717.2.0000.5153).

\section{RESULTS}

The identification and training of nurses' skills for coping with social inequalities in the PHC based on knowledge, skills and attitudes they may recognize as necessary to act assertively in relation to this reality.

Thus, from the analysis, three thematic categories emerged, namely: "Knowledge to work the social inequalities in health in Primary Care", "Acquired skills to work the social inequalities in Primary Care" and "Nurses' attitudes in the coping process of social inequalities in Primary Care".

\subsection{Knowledge to work the social inequalities in health in Primary Care}

In relation to the formation of competence to act in the context of social inequalities, the nurses point out the knowledge necessary to cope with this reality. In this sense, they indicate as essential the knowledge and identification of their role in this scenario, as well as the role and functioning of the health care network $(\mathrm{HCN})$, as well as the knowledge about the laws that can assist them in coping with social inequalities in health:

[...] we pointed out a lot [...] we also see that they (the Health Care Network) experience difficulties and have their limitations too, but it is important for us to understand the other side because we tend to judge a lot. (G2)

[...] for me, knowledge, chase perfection, knowing the programs because not only the sector has to know, I also have to because I'm the gateway to go there to help, to know how to guide so I have to know [...], I have to understand at least the program's goal, for me to know how to help, for me to know how to guide, to know others' right [...] so we know, seeking knowledge I think is my main role. (G3) 
[...] I think it is important that we have this knowledge of who is responsible for each thing [...] I also think it is important to know the legislation, the attributions, of these actors, these scenarios. That was the biggest difficulty we had, knowing what CREAS is, what CRAS is, what each one does, what is each's responsibility [...] that we can delegate functions, knowing that this is not mine, that this is the responsibility of this sector [...] to know how to direct [...]. (G5)

[...] we are not alone, we have other sectors, when we can look for someone [...]. (G1)

[...] there are too many important programs, but we had no knowledge of any of them, and to whom to delegate, to whom to ask for help, to whom to ask for support, and not even the sectors themselves knew of the importance that we had in acting together with them [...] in the workshops, this dialogue began. They (other actors in the Health Care Network) saw that we didn't have much knowledge, but that we had a lot of demand and that they had a lot of demand that could have been better assisted if they were communicating with Primary Care. (G3)

[...] now I know that this communication, which was what we saw in the workshop, is what will move all of this [...] the biggest problem is also the solution (G5)

\subsection{Acquired skills to work the social inequalities in Primary Care}

The research participants reveal that the knowledge built in the workshops allowed them to acquire skills, to know how to act in the face of social inequalities in health. In this sense, they are able to discern, in the work process, strategies of how to make the coping process, understanding their role and the other's in this context and becoming calm in respect to their professional competence:

[...] we start to learn to delegate, live with other sectors, live with the team (G1)

[...] in relation to the issues we can often help, which is our competence we sometimes did not know about [...] in terms of reception, of receiving the user, of showing that you can help him [...] now I can see that we can help on some points, refer him

Ci. e Nat., Santa Maria, v.43, Ed. Esp. UFV,e11, 2021 
correctly to another professional, ask him for feedback: what did you think? Did you really need it? Was that it? What else can we do together? Let's do it this way (G2).

[...] now we also have more openness to be able to communicate with them (the other actors and sectors) because we haven't had that until then. (G2)

[...] I am not the eyes of the community agent, but he also has to know how to act on it [...] since I'm the team's reference, I'm responsible for passing this on to him [...] expand this bigger vision for the whole team [...] I can go there to help, do, solve, but he can also [...] I have the competence to open his eyes, to make him look, you know, and where to look. That was very clear to me. (G3)

[...] tranquility, personal growth, professional competence, opening up a network, knowing who to work with, who to look for, who to ask for support and also another look at the other's experience, because there were a lot of judging eyes [...] it brings me a lot of tranquility, much more patience, much more humanity, even to look for these professionals (from the Health Care Network) [...]. (G3)

[...] I know my role, I can do my part in relation to social inequalities and I have someone to look for, to whom to send that patient [...] From the moment you know the person who works in that sector whether or not you create a greater bond, I know where it goes, what it will do, and what it will not do [...]. (G4)

[...] I believe that in my personal world I can do much more [...] I have more knowledge and the expectation to share this knowledge with the team, to do the best for our community. (G5)

We can look for partners [...] I know that I will be able, in the face of a situation, to turn to other people, and if that is not within my competence, nor within my reach, I will also know how to speak. Today I feel less guilty in doing this. (G6)

[...] we can, at that moment, modify the service or improve how we are in relation to the team, in relation to the attributions of the sectors, learn to delegate more functions, to pass on knowledge to the whole team and try somehow to keep stimulating everybody, encouraging them to walk and improve. (G6) 


\subsection{Nurses' attitudes in the coping process of social inequalities in Primary Care}

To build knowledge and skills, participants started to recognize in their everyday experiences the dimension of attitudes for coping with the social inequalities. In this sense, they highlight the reception and home visits as a professional practice in which they perform the equitable care and recognize, based on the needs of the population, the importance of support from other actors and sectors in their work with social issues:

[...] at the reception, we evaluate patients and see what can be done for them [...] it's very important, at least we are doing our referral, our role of detecting, referring, asking for support, I think this part is very important, of us identifying and doing something for people. (G2)

[...] the home visit is an opportunity for us to see the reality of the family, that patient [...] help in a clearer way, according to the culture of each one [...] to assist them according to their specificities [...] this way, we have to try to work and pay more attention to these people [...] pay more attention to those who really need most. (G2)

[...] I hear what the person was looking for, I hear the whole reality. At the reception, you give them the importance of listening, of what they came to talk about, the need or not in the face of the social issue and even other issues [...] then you start to analyze, start to think: "this would fit here! Look, this is triggering this problem, I work this social issue, here I need help [...] (G3)

The nurses start to work in a more assertive way to act in the face of reality of social inequalities, applying the knowledge and skills acquired in their daily work. In this context, there stands out the practice of communicating, aggregating and co-involving other actors to cope with this reality, as the team itself and the Expanded Core of Family Health (NASF):

[...] sometimes you are so used to going there and seeing that family like that [...] I have some food left over in my house, I give you, you know? It's so-and-so that helps, right? So I went by and 
said: "he can receive LOAS and she can get a work assistant, right? [...] I didn't know anything about LOAS, so sought what I needed, and it's easy [...] and so I don't want to miss it. Do you know why? I want this to work for the whole team, right? So that you can see the improvement of the social condition [...]One micro-area passes to the other, which covers the entire area. This is of paramount importance. (G3)

[...] my whole team now knows the issue of CRAS, CREAS, because every time I have a meeting, I pass it to them, where to look, who to look for [...] I started showing it to the team, that they also have some responsibility [...] (G4)

At the matrix meeting, I sit down with the NASF team to discuss those cases that need referral to them [...]. (G5)

[...] today we are able to communicate more, we are able to seek more people involved in this scenario to help [...] This is what I will take from here. (G6)

\section{DISCUSSION}

The results of this investigation reveal the skills necessary for the nurse work the social inequalities in health. Such skills were drawn from the knowledge, skills and attitudes, which, together, enable the accomplishment of professional activities with better performance (LEONELLO; OLIVEIRA, 2008). These three elements reflect, respectively, the learning, learning to do and professional doing, considered essential for the formation of a competent nurse in his/her area of expertise.

When we consider the performance on social inequalities in health, there is need to add other perspectives to the universe of skills training, rescuing the recommendations of the International Commission on Education for Twenty First Century. This presents four pillars that must support the education, represented by learning to know, learning to do, learning to be and learning to live together (LEONELLO; OLIVEIRA, 2008; DELORS et al., 2010). 
The learning to know refers to knowledge built over the course of everyday life, leading to a continuous learning. The learning to do implies articulating the technical preparation and personal and relational aptitudes, which involve teamwork, initiative and decision-making in relation to their professional performance. The learning to live together relates the collective construction of individuals while seeking common goals. Finally, the learning to be is based on social commitment and involvement of the subject to transform his/her reality (LEONELLO; OLIVEIRA, 2008).

Thus, in the present study, the creation of skills built by nurses to act on social inequalities in health $(\mathrm{SIH})$ is also included in the light of these pillars. Moreover, evidently, these skills produce a dialog with those laid down for this professional in the National Curricular Guidelines (NCG) of the Nursing course, such as health care, decision making, communication, leadership and continuing education (BRASIL, 2001).

Regarding the nurse's knowledge to work the social inequalities in the PHC context, the study highlights the importance of this professional recognize his/her role and of the other professionals in the $\mathrm{HCN}$, in order to contribute to their activities outside the complexity related to social issues in the PHC. Arruda et al. (2015) affirm that the professional's recognition about his/her role in the health care network contributes to a greater effectiveness of the actions provided. In contrast, the unawareness of the role of the other participating agents of the network corroborates a fragmented and isolated practice among the sectors (ARRUDA et al., 2015)

Another point highlighted in this study was the knowledge, by nurses, of the functioning of the sectors and laws available for coping with these inequalities, emphasizing that such knowledge allowed them understand the strengths and limitations present in sectors that compose the HCN. 
This competence is of fundamental importance for the professionals who work in the PHC, since the knowledge of these professionals is commonly limited on the sectors and laws that govern the health care, which directly results in a lower resolvability of the health services and actions (PEITER et al., 2019)

Thus, the knowledge about the human and material resources that compose the HCN allows nurses to form an enlarged view about the devices necessary to assist them in coping with social inequalities. This research highlights the resignification the devices themselves, highlighting that the agents' knowledge (possible in the third workshop) has encouraged the participants to develop, in conjunction, their actions to cope with inequalities.

This reflects the legitimation of one of the basic skills provided to the nurse in the NCG: health care. In this jurisdiction, this professional should ensure that his/her practice is performed in an integrated and continuing way with the other devices listed in the UHS. It also considers that the responsibility of health care is not limited to the technical act, but extended to the resolution of the individual and collective problems (BRASIL, 2001), constituting as a guideline for the actions concerning the nurse's performance in the face of social inequalities.

In this way, for a continuous flow in the $\mathrm{HCN}$, there is need for a permanent dialog between its members, in order to facilitate the dynamics and team work between those involved (COSTA et al., 2015). As evidenced in the results of this study, the importance of communication between the HCN points is an acquired knowledge recognized by nurses as of paramount importance in their professional practice.

The literature confirms such importance when revealing that the dialog in the HCN is still a challenge for those working within the UHS. Those varied network interconnections end up generating conflicts and problems in integration and communication between the different actors and sectors (COSTA et al., 2015), which is still incipient compared to the complex web required in dialog for the coping with social inequalities in health. 
Furthermore, the competence of communication should take precedence for the professionals who work in the PHC complexity, which, as HCN advisor, has the primary role of organizing and promoting effective communication between the points of health care, enabling an articulation of actions performed with the needs of individuals and collectivities (COSTA et al., 2015).

In this context, interdisciplinary and intersectoral actions should be highlighted, in order to strengthen the horizontal relationships between the actors and sectors that compose the HCN. This implies the exploitation of integrative knowledge and practices, strengthening the performance in conjunction for a comprehensive approach on the health-disease process (COSTA et al., 2015), a sine qua non condition to work the social inequalities in health.

Such understanding, built by nurses during the workshops, allowed them see themselves not as central elements of the coping strategies of social inequalities, but as responsible in this process, recognizing their role and of other professionals in the complex plot to be woven facing this reality.

Concerning the skills - which refer to the learning to do - it is possible to identify in the present investigation a resignification concerning responsibilities and competences developed by nurses for their actions on social inequalities. In this sense, there stands out the identification of their role and actions they can put into practice in daily work processes, particularly demonstrating ability for decision-making and communication, basic competences of nurses also laid down in the NCG (BRASIL, 2001)

The ability to communicate and make decisions is intimately linked to the production of the labor alive in the act, which is carried out by the human being based on processes and relationships. Such skills are able to modify the actions in the micropolitics of the professional workplace, ensuring greater assertiveness in everyday practices (FRANCO; MERHY, 2013). 
There is evidence of changes in the nurse related to the recognition of his/her role in dealing with the social inequalities that could be exemplified in the skills developed in workshops and unfolded in concrete possibilities of actions to cope with inequalities in the micropolitics of his/her work process.

Such evidence is of great importance, since national and international researches indicate a weakness in the nurse's political activity, which places him/her as a subject promoter of changes in social reality. This fragility affects the social and ethical commitment they must assume regarding the problems of the population, also interfering in the delineation of their professional identity and, consequently, in the performance of their competences (FERNANDES et al., 2018; BUCKMCFADYEN; MACDONNELL, 2017).

Therefore, the skills developed by nurses in the present investigation strengthen the political dimension of their practice. They also reflect an appropriation of their learning to do and of the others in the coping process of social inequalities, producing displacements in the dimension of the learning to be and learning to live together (DELORS, et al., 2010), which refer respectively to the conscience of their social responsibility in this context and the need to communicate knowledge and different practices, managing to express such skills developed in typical situations experienced in their professional routine.

This allows the nurse to recognize his/her activity in the PHC as a social practice, approaching the demands emerged by society to his/her core of knowledge and professional competences. This professional is expected to be able to perform continually actions that allow his/her own transformation and of the social reality surrounding him/her (FERREIRA; PÉRICO; DIAS, 2018), which was also evidenced in this research.

With regard to the attitudes developed, the research participants began to recognize in their daily practices - as in the reception and home visit - their actions in the face of social inequalities. The literature shows that, in fact, such practices can guide the professional activity in this context, since the home visit and the 
reception are capable of contributing to the identification of the real needs of users, as well as the understanding of social problems (PINTO et al., 2017).

In the present investigation, these everyday tasks of the nurse in the PHC began to be seized as an opportunity for this professional act on inequalities, through the recognition of the real individual and collective needs and of a performance that meets the demands of each social reality. This is translated as an equitable care and, therefore, able to mitigate social inequalities in his/her territory.

The equitable care can also be understood as a way to offer care with greater resolubility, requiring a professional social commitment. Seeking to offer an equitable care, nurses need to understand the inequities in health, their origin and influence on the health of subjects (BUCK-MCFADYEN; MCDONNELL, 2017), which is also vital for their actions with competence on the social inequalities.

It is important to highlight that the formation of competence to act in this context allowed study participants not only reframe the practices previously performed as promoters of an equitable care. It reached other spaces, which, until then, they were unaware of, strengthening the dimension of attitude to cope with inequalities in the territory.

In this sense, the supported knowledge and skills allowed nurses to act consistently with the luggage they had for such coping process. Despite this performance, there stands out the incorporation of assertive attitudes to cope with social inequalities, such as the communication practice (with actors from the PHC and other sectors) and to guide and work together with the population, providing knowledge to them in relation to social rights assured through programs and specific legal devices for each different situations they experience in the ter ritory.

This dimension of attitude developed strengthens the pillars of learning to be and learning to live together, preceded by learning to know and learning to do, which, in conjunction, give the education the ability to meet the demands emerged in society in the current century (LEONELLO; OLIVEIRA, 2008). 
Considering that the nurse acts in this society, he/she is responsible for keeping in ongoing process of formation to give effective responses to emerging social problems. This makes him/her part of other basic competences laid down in the NCG: continuing education and leadership (BRASIL, 2001).

The nurse, when assuming the role of team leader in the PHC context, equipped with knowledge and skills to cope with inequalities, he/she acts as an articulator and generator of competences for this coping process with the other team members, making them co-responsible in this process.

In this context, there is the permanent education (PE) as an important strategy for the acquisition of competences in coping with these inequalities, which was also experienced by nurses themselves in the process of collective construction of the workshops carried out in this research. The PE allows developing a learning from the problematization of the work process, aiming to change, transform and overcome the difficulties found in the reality experienced by professionals, directing and redirecting care practices (SILVA; MATOS; FRANCA, 2017).

This was evidenced in the study participants who, when problematizing a critical node of their work process (the social inequalities), they were mobilized to build competences to untie it, contributing to a change of attitude to this reality. Therefore, reflecting on this critical node allowed nurses recognize and incorporate into their practice communication and the search for new knowledge, assuming, in some moments, the role of learners and, in others, the role of the educator of their team.

In this sense, according to the literature, the PE provokes the transformation of social practices through the construction and reconstruction of knowledge among professionals, culminating in qualification and co-responsibility of the assistance between all subjects involved (SILVA; MATOS; FRANCA, 2017). This places the nurse as co-participant in the coping process of social inequalities in health, overthrowing him/her from their position perceived prior to the research-action: 
as the center and only responsible for meeting the complexity of the social demands emerging in the PHC.

The study presented as a limitation the fact of its development in a particular context. Studies in different realities can lead to also distinct findings, preventing the generalization of the results. Nonetheless, considering that the research object reflects a problem of global order in the country, the formation of competences here announced represent important tools for coping with inequalities in health by professionals who work in Primary Care.

\section{CONCLUSIONS}

This research allowed identifying, through the research-action, the competences built by PHC nurses to act on social inequalities in health. Such evidence adds substantial value to the scientific production on this topic, which, although incipient, translates as of extreme importance for this professional be able, with his/her practice, to offer social responses in the reality surrounding him/her.

Such competences were interpreted from the knowledge, skills and attitudes that support, under the perspective of the four pillars of education established by UNESCO (to know, to do, to be and to live together) and considering their interface with those laid down for the nurse in the NCG of the Nursing Course.

The methodological trajectory travelled in the study could be understood as a permanent education process for the research participants who, when reflecting on their practices in the coping process of social inequalities in health, were conducted to resignifications of their learning to know and to do in this field, forming competence to act in this context. In this trajectory, they were transformed and, in parallel, acted as agents of transformation in the micropolitics of the working process built to a more aware and assertive coping process about the social inequalities they experience in the territory. 
In this sense, there stands out the importance of the dimension of learning to live together, translated from the communicational skills and attitudes built by nurses with other actors and sectors that act on the social inequalities, which consisted, in this study, as the central axis regarding the competences formed. As developments, there was a reconfiguration of the nurse's identity, who, before the workshops, understood him/herself and stood as the only responsible for conferring social responses that transcended his/her professional competence and work.

The findings of the present study indicate the importance of appreciating and strengthening the training of nurses in the development of competences to act on social inequalities, which is still incomplete. This investment should occur with those responsible for the teaching in graduate and postgraduate programs, resulting in theoretical and practical approaches for coping with these inequalities.

For those who work in the professional context - both in micro as macromanagement - there should be an incentive and a continuous increment of movement of permanent education in this field, so that these professionals may, within their levels of competence and work, meet the needs of intervention on the social inequalities in health. The permanent education should include all actors and sectors involved in this complex context in the territory, which reflects a public health problem present in the way the Brazilian society has historically constituted.

\section{REFERENCES}

AITH F, SCALCO N. Direito à saúde de pessoas em condição de vulnerabilidade em centros urbanos. Rev. USP. [Internet]. 2015 [cited $2017 \mathrm{fev}$ 10];(107):43-54. Available from: http://www.revistas.usp.br/revusp/article /view/115112/112817.

ARANTES LJ, SCHIMIZU HE, MERCHÁN-HERMANN E. Contribuições e desafios da Estratégia Saúde da Família na Atenção Primária à Saúde no Brasil: revisão da literatura. RC\&SC [Internet]. 2016 [cited 2017 fev 10];21(5): 1499-1509. Available from: http://www.scielo.br/scielo.php?pid=S1413-81232016000501499\&script=sci_abstract\&tlng=pt. 
ARRUDA C et al. Redes de atenção à saúde sob a luz da teoria da complexidade. EEAN [Internet]. $2015 \quad$ [cited 2017 jan 10];19(1):169-173. Available from:http://www.scielo.br/scielo.php?script=sci_arttext \&pid=S1414-81452015000100169.

BARDIN L. Análise de conteúdo. 70st ed. Lisboa 2016.

BARRETO ML. Desigualdades em Saúde: uma perspectiva global. RC\&SC [Internet]. 2017 [cited 2020 fev 23];22(7):2097-2108. Available from:http://www.scielo.br/scielo.php?pid=S1413$81232017002702097 \&$ script=sci_abstract $\&$ tlng=pt.

BARROS FPC, SOUSA MF. Equidade: seus conceitos, significações e implicações para o SUS. Saúde Soc. [Internet]. 2016 [cited 2017 fev 10]; 25(1):9-18, 2016. Available from:http://www.scielo.br/scielo.php?pid=S0104-12902016000100009\&script=sci_abstract\& tlng=pt.

BORGES MAR, AMARAL AF. A desigualdade social e suas influências na subjetividade contemporânea. Rev. Psicol. Saúde em Debate [Internet]. 2015 [cited 2017 fev 10];1(2). Available from:http://psicodebate.dpgpsifpm.com.br/index.php/periodico/article/view/19/11.

BRASIL. Ministério da Educação; Conselho Nacional de Educação. Câmara da Educação Superior. Resolução n 3/01- Institui Diretrizes Curriculares Nacionais do Curso de Graduação em Enfermagem. Brasília(Brasil): Ministério da Educação e Cultura; 2001. Resolução n 3, de 07 de novembro de 2001. Institui Diretrizes Curriculares Nacionais do Curso de Graduação em Enfermagem. Distrito Federal (Brasil);2001.

BRASIL; Constituição da República Federativa do Brasil. Promulgada em 5/88- ; Constituição da República Federativa do Brasil. Brasília (Brasil): Brasil; 1988.

BUCK-MCFADYEN E, MACDONNELL J. Contested practice: political activism in nursing and implications for nursing education. Int. J. Nurs. Educ. Scholarship [Internet]. 2017 [cited 2018 mai 15]. Available from:https://www.ncbi.nlm.nih.gov/pubmed/28749781.

BUSS PM, PELLEGRINI FILHO A. A saúde e seus determinantes sociais. PHYSIS: Rev. de Saúde Coletiva [Internet]. 2007 [cited 2017 fev 10];17(1): 77-93. Available from:http://www.scielo.br/scielo.php?pid=s0103-73312007000100006\&script=sci_abstract\& tlng=pt.

COSTA CFS et al. A complexidade da rede de atenção à saúde. Cienc. Cuid. Saude [Internet]. 2015 [cited 2018 mai 15];; 14(4): 1609-1615. Available from:http://periodicos.uem.br/ojs/index.php/CiencCuidSaude /article/view/27791/pdf.

DELORS J et al. Educação: um tesouro a descobrir [Internet]. Brasília: UNESCO [cited 2017 jan 20]. Relatório para a UNESCO da Comissão Internacional sobre Educação para o Século XXI 2010. Available from http://unesdoc.unesco.org/images/0010/001095/109590por.pdf. 
FERNANDES JD. et al. Aderência de cursos de graduação em enfermagem às diretrizes curriculares nacionais na perspectiva do sistema único de saúde. EEAN [Internet]. 2013 [cited 2017 fev 10];17(1):82-89. Availablefrom:http://www.scielo.br/scielo.php? script=sci_arttext\&pid=S1414-81452013000100012.

FERNANDES MC. et al. Identidade do enfermeiro na atenção básica: percepção do "faz de tudo". Rev. Bras. Enferm. [Internet]. 2018 [cited 2018 mai 15];71(1):154-159. Available from: http://www.scielo.br/scielo.php?pid=S0034-71672018000100142\&script=sci_abstract\& tlng=pt.

FERREIRA SRS, PÉRICO LAD, DIAS VRFG. A complexidade do trabalho do enfermeiro na atenção primária à saúde. Rev. Bras. Enferm. [Internet]. 2018 [cited 2018 mai 15];71(1):752-757. Available from:http://www.scielo.br/scielo.php?script=sci_arttext\&pid= S003471672018000700704\&lng= en\&nrm =iso\& tlng=pt.

FERTONANI HP et al. Modelo assistencial em saúde: conceitos e desafios para a atenção básica brasileira. RC\&SC [Internet]. 2015 [cited 2017 fev 10];20(6):1869-1878. Available from: http://www.scielo.br/scielo.php?script=sci_arttext\&pid=S1413-81232015000601869.

FRANCO TB, MERHY EE. Trabalho, produção do cuidado e subjetividade em saúde. 1st ed.São Paulo: Hucitec; 2013.

Instituto Brasileiro de Geografia e Estatística [Internet]. Brasília: Ministerio do planejamento, Orgameto e Gestão (BR) [cited 2016 dez 31]. Estimativas da população residente no Brasil e unidades da federação com data de referência em $1^{\circ}$ de julho de 2015 . Available from:ftp://ftp.ibge.gov.br/Estimativas_de_Populacao/Estimativas_2015/estimativa_dou_201 5_20150915.pdf.

LEONELLO VM, OLIVEIRA MAC. Construindo competências para ação educativa da enfermeira na atenção básica. Rev. Esc. Enferm. USP [Internet]. 2008 [cited 2018 fev 23];41(Esp):847-52. Available from: http://www.scielo.br/scielo.php?pid=S008062342007000500019\&script=sci_abstract\&tlng=pt.

PAIM J et al. O sistema de saúde brasileiro: história, avanços e desafios. Lancet (Serie Brasil) [Internet]. 2011 [cited 2017 fev 10]:11-31. Available from: https://www.thelancet.com/pb/assets/raw/Lancet//pdfs/brazil/brazilpor1.pdf.

PEITER CC. et al. Redes de atenção à saúde: tendências da produção de conhecimento no Brasil. EEAN [Internet]. 2019 [cited 2020 fev 23];23(1). Available from: http://www.scielo.br/scielo.php?script=sci_arttext\&pid=S1414-81452019000100801\&lng= en\& $\mathrm{nrm}=$ iso\&tlng=pt.

PINTO AGA. et al. Vivências na estratégia saúde da família: demandas e vulnerabilidades no território. Rev. Bras. Enferm. [Internet]. 2017 [cited 2018 mai 15];70(5):970-977. Available from: http://www.scielo.br/scielo.php?script=sci_arttext\&pid=S0034-

71672017000500920\&Ing=en\&nrm=iso\&tlng=pt. 
SCHVINGEL C, GIONGO IM, MUNHOZ AV. Grupo focal: uma técnica de Investigação qualitativa. Rev. Debates Educ. [Internet]. 2017 [cited 2017 fev 10];9(19). Available from:http://www.seer.ufal.br/index.php/debateseducacao/article/view/3455/pdf.

SILVA KL, MATOS JAV, FRANCA BD. A construção da educação permanente no processo de trabalho em saúde no estado de Minas Gerais, Brasil. EEAN [Internet]. 2017 [cited 2018 mai 15];21(4). Available from:http://www.scielo.br/scielo.php?pid=S1414$81452017000400204 \&$ script=sci_abstract\&tlng=pt.

THIOLLENT M. Metodologia da pesquisa-ação. 7st ed. São Paulo: Cortez; 2008.

TRIPP D. Pesquisa-ação: uma introdução metodológica. Educação e Pesquisa [Internet]. 2005 [cited 2017 fev 23];31(3):443-466. Available from:http://www.scielo.br/scielo.php?pid=S1517$97022005000300009 \&$ script=sci_abstract $\&$ tlng=pt.

\section{Authorship contributions}

\section{1 - Nayara Rodrigues Carvalho}

Mestre em Ciências da Saúde pela Universidade Federal de Viçosa.

https://orcid.org/0000-0002-5037-6351 - nayara-rcarvalho@hotmail.com

Contribuição: Conceptualization; Data curation; Formal Analysis; Funding acquisition; Investigation; Methodology; Resources; Software; Writing - original draft.

\section{2 - Andréia Patrícia Gomes}

Professora Adjunto do Departamento de Medicina e Enfermagem da Universidade Federal de Viçosa-MG, Doutora em Ciências pela Fundação Oswaldo Cruz. https://orcid.org/0000-0002-5046-6883 - andreiapgomes@gmail.com Contribuição: Writing - review \& editing.

\section{3 - Érica Toledo de Mendonça}

Professora Adjunto II do Departamento de Medicina e Enfermagem da Universidade Federal de Viçosa-MG, Doutora em Ciência da Nutrição da Universidade Federal de Viçosa.

https://orcid.org/0000-0002-8395-0858 - ericapoty@yahoo.com.br Contribuição: Methodology.

\section{4 - Amanda Morais Polati}

Mestranda em Saúde Coletiva pela Universidade Federal do Espírito Santo. https://orcid.org/0000-0003-3713-681X - amandapolati07@gmail.com Contribuição: Investigation; Methodology; Writing - original draft.

\section{5 - Vanessa de Souza Amaral}

Mestre em Ciências da Saúde pela Universidade Federal de Viçosa. 
https://orcid.org/0000-0002-8435-2868 - amaralsvanessa@gmail.com Contribuição: Methodology.

\section{6 - Tiago Ricardo Moreira}

Professor Adjunto I do Departamento de Medicina e Enfermagem da Universidade Federal de Viçosa-MG, Doutor em Saúde Pública na Universidade Federal de Minas Gerais.

https://orcid.org/0000-0002-6606-4942 - tiagoricardomoreira@gmail.com Contribuição: Writing - review \& editing

\section{7 - Deíse Moura de Oliveira}

Professora Adjunto do Departamento de Medicina e Enfermagem da Universidade Federal de Viçosa-MG. Doutora em Ciência da Saúde pela Universidade de São Paulo. https://orcid.org/0000-0003-3804-7413 - dmouradeoliveira@gmail.com Contribuição: Project administration; Supervision; Methodology; Writing - review \& editing. 